\title{
Sejm koronacyjny w 1507 roku w Krakowie
}

\author{
Krönungsreichstag im Jahre 1507 in Krakau
}

\begin{abstract}
...exactiones non ex debito seu obligatione, sed de libera spontaneaque voluntate ac merito arbitrio laudarunt

[podatki nie z musu czy obowiązku, lecz $z$ wolnej i nieprzymuszonej woli, a także ze shusznego przekonania uchwalili]

Zygmunt I w poręczeniu wolności podatkowych, 8 marca 1507 r. (Corpus Iuris Polonici III, nr 13, s. 50); przekł. W.U.
\end{abstract}

1. Przygotowanie sejmu walnego 1507 r. 2. Uczestnicy sejmu. 3. Przebieg. 4. Postanowienia: 4.1. Konstytucje doraźne; 4.2. Konstytucje wieczyste. 5. Inne formy aktywności sejmu. 6. Podsumowanie. 7. Aneks.

1. Vorbereitungen auf den Reichstag 1507 2. Beteiligte am Reichstag. 3. Beratungen. 4. Beschlüsse: 4.1. Vorläufige Verfassungen; 4.2. Ewige Verfassungen. 5. Andere Aufgaben des Reichstags. 6. Resümee. 7. Annex.

1. Propozycję zwołania sejmu walnego w Krakowie zaraz po koronacji Zygmunta Jagiellończyka na króla Polski wysunął na zjeździe elekcyjnym kanclerz Jan Łaski ${ }^{1}$. W intencji kanclerza, zadaniem sejmu miało być naradzenie się nad sposobem obrony państwa przed najazdami Tatarów i Turków. Inicjatywa ta zyskała przychylność senatu, który jeszcze podczas elekcji zdecydowal o zwołaniu do Krakowa sejmu walnego².

L. F inkel, Elekcja Zygmunta I. Sprawy dynastii jagiellonskiej i unii polsko-litewskiej, Kraków 1910, s. 170-190.

2 Ibidem. Zob. też: Akta Stanów Prus Królewskich [dalej: ASPK] t. V, wyd. M. Biskup, Warszawa-Poznań 1973-1974, cz. 1, s. 15. 
Od końca wieku XV zwoływanie sejmu walnego poprzedzano ekspedycją tzw. listów sejmowych (litterae conventuales). W ich skład wchodziły królewskie listy do Panów Rady ,starszych” (ad maiores consiliarios, senatores) i „młodszych" (iuniores), uniwersały adresowane do ogółu szlachty (litterae universales), mandaty do starostów i legatów królewskich na sejmiki. W uniwersałach król wzywał rycerstwo do udziału w sejmikach i wyboru posłów $\mathrm{z}$,,pełną mocą stanowienia" (cum plena potestate). Do legatów wysyłano ponadto tzw. kredencje, czyli pełnomocnictwo, oraz tekst legacji królewskiej ${ }^{3}$.

Tego rodzaju dokumenty w odniesieniu do sejmu koronacyjnego z $1507 \mathrm{r}$. nie zachowały się. Znamy jedynie list króla do rady Miasta Gdańska wysłany z Mielnika z datą 1 stycznia 1507 r., wzywający do przysłania posłów na koronacje i na sejm walny do Krakowa ${ }^{4}$. Na podstawie tego listu można zasadnie przypuszczać, że uprawnienie do zwołania sejmu koronacyjnego należało do króla-elekta. Odpowiadało to normie prawnej, że wezwanie do udziału $w$ sejmie musiało być więc zawsze dokonywane $w$ imieniu króla 5 .

Nic nie wiemy o przebiegu obrad sejmików przedsejmowych, na których doszło do wyboru posłów ziemskich z poszczególnych województw Korony. Jedyna znana relacja $z$ takiego sejmiku odnosi się do zjazdu stanów Prus Królewskich w Elblągu, w okresie od 30 grudnia $1506 \mathrm{r}$. do 1 stycznia $1507 \mathbf{r}^{6}{ }^{6}$ Wydelegował on do Krakowa posłów w osobach wojewody pomorskiego Mikołaja Wulkowskiego i kasztelana gdańskiego Mikołaja Szpota?. $Z$ późniejszego przebiegu sejmu, a zwłaszcza dzięki znajomości podjętych na nim uchwał, wiadomo, że zebrana na sejmikach szlachta koronna udzieliła posłom pełnej mocy stanowienia (plena potestas, plena facultas, sufficiens instructio $)^{8}$. Warunkowało to pomyślny przebieg obrad. Należy zaznaczyć, że plena potestas udzielona posłom $w$ sprawach inicjowanych „od tronu", gdzie zwykle chodziło o sprawy obrony, nie wykluczała ani instrukcji sejmikowych w ogólności, ani ograniczonej mocy (limitata potestas)

${ }^{3}$ Zob. W. Uruszczak, Sejm walny koronny w latach 1506-1540, Warszawa 1980, s. 69-79.

4 ASPK V, cz. 1, nr 14, s. 40 - regest.

${ }^{5}$ Zwoływanie zgromadzeń bez zgody króla stanowiło zbrodnię obrazy majestatu (crimen laesae maiestatis). Por. W. Uruszczak, Korektura praw z 1532 roku. Studium historycznoprawne, Ł. II, Warszawa-Kraków 1991, s. 63 i n.

${ }^{6}$ Por. reces zjazdu Stanów Prus Królewskich w Elblągu w dniach 30 XII 1506 r. - 1 I 1507 r. publik. w ASPK V, cz. 1, nr 13, s. 23-39, a także instrukcję rady Gdańska dla jej posłów na zjazd w Elblągu, ibidem, nr 12, s. 21-23.

${ }^{7}$ Por. reces zjazdu stanów pruskich w Grudziądzu 11 IV 1507 r., na którym posłowie stanów pruskich złożyli sprawozdanie z rozmów z królem i dygnitarzami Korony, ASPK V, cz. l, nr 33, s. 78 .

${ }^{8}$ Dowodzi tego wzmianka $w$ art. 1 uchwalonych na sejmie konstytucji: ...immo verius totius senatus et nobilitatis, cuius nuntii cum plena facultate ex singulis regni terris ad consultandum nobiscum de futuro statu regni huc convenerant..., Volumina Constitutionum Tom I (1493-1549), volumen 1 (1493-1526), wyd. S. Grodziski, J. Dwornicka, W. Uruszczak, Warszawa 1996 [dalej: VC], s. 187-188. 
w innych sprawach. Było regułą, że posłowie ziemscy przybywali na sejm $\mathrm{z}$ listą tzw. petytów ustawodawczych, czyli próśb do króla i senatu o uchwalenie danej ustawy'.

2. W obradach sejmu koronacyjnego uczestniczyło 34 senatorów ${ }^{10}$. Byli wśród nich dwaj metropolici oraz prawie wszyscy biskupi, w lącznej liczbie ośmiu. Wakowało krzesło biskupa kamienieckiego, Jakuba Buczackiego. Licznie stawili się wojewodowie (pięciu z Małopolski oraz siedmiu z Wielkopolski), w gronie których brakowało jedynie wojewodów podolskiego, płockiego i lubelskiego. Znacznie słabiej przedstawiała się frekwencja kasztelanów. Do Krakowa zjechało ich zaledwie jedenastu: dziewieciu z Małopolski oraz tylko dwóch z Wielkopolski. Nie przybyli nawet ci, którzy wcześniej bawili na elekcji w Piotrkowie. Natomiast na sejmie byli obecni wszyscy ministrowie, a więc obydwaj marszałkowie oraz obaj kanclerze, a także podskarbi. Dwóch $\mathrm{z}$ nich (to jest podkanclerzy oraz podskarbi) sprawowało równolegle inne godności senatorskie ${ }^{1 !}$.

W sejmie - pomimo królewskiego zaproszenia - nie uczestniczyli przedstawiciele Gdańska. Zapowiedzieli to już podczas elekcji w Piotrkowie. W liście pisanym z Piotrkowa, po 8 grudnia 1506 r. do Zygmunta, posłowie Gdańska poinformowali go, że Rada Miasta nie będzie mogła wysłać poselstwa na sejm koronacyjny $z$ powodu niepewnych dróg ${ }^{12}$. Stanowisko to Gdańszczanie podtrzymali na wspomnianym już zjeździe w Elblągu, odmawiając partycypacji w pokryciu kosztów poselstwa Prus Królewskich do króla ${ }^{13}$. Najprawdopodobniej był to wybieg spowodowany ukrytym zamiarem nieuczestniczenia we wspólnym poselstwie pruskim. Najbogatsze miasto Rzeczpospolitej preferowało bezpośrednie rozmowy z królem i najwyższymi dostojnikami Korony, upatrując w nich lepszy sposób realizacji swoich interesów. Specjalny wysłannik rady Gdańska do króla, magister Ambroży Storm, dotarł do Krakowa dopiero pod koniec obrad sejmowych - w dniu 23 lutego $1507 \mathrm{r}^{14}{ }^{14}$ Jego zadaniem było uzyskanie królewskiego poparcia w szeregu pilnych sprawach $^{15}$.

${ }^{9}$ Zob. W. Uruszczak, Sejm walny..., s. 45 i n.

${ }^{10} \mathrm{~W}$ początkach panowania Zygmunta I $\mathrm{w}$ radzie królewskiej zasiadało: 2 arcybiskupów i 7 biskupów, 14 wojewodów, 59 kasztelanów i 5 ministrów - lącznie 87 osób.

${ }^{11} \mathrm{~W}$ sprawie frekwencji senatorów na sejmach Zygmunta I zob. W. Uruszczak, Sejm walny..., s. 29-37. Por. też interesujące uwagi Jana Seredyki o znaczeniu badań w tym zakresie zamieszczone w pracy pt. Parlamentarzyści polscy od końca $X V$ wieku do 1632 roku, [w:] Parlamentarzyści polscy od XVI do XX wieku. Stan badań i postulaty, red. J. Seredyka, współudz. D. Kurpiers-Schreiber, Opole 1999, s. 11-17.

12 ASPK V, cz. I, nr 11, s. 19.

${ }_{13}$ Zob. ASPK V, cz. 1, nr 13, s. 33 i n.

${ }_{14}$ Por. list A. S torma do Rady Gdańska z 28 II 1507 r., ASPK V, cz. 1, nr 18, s. 42-51.

is Por. instrukcję rady gdańskiej dla jej posła, ASPK V, cz. 1, nr 17, s. 42-49. 
Akta Stanów Prus Królewskich zawierają szereg dokumentów świadczących, że podczas sejmu koronacyjnego - choć nie na sejmie - król podjął wiele decyzji w sprawach przedłożonych mu przez posła gdańskiego, między innymi: przyznanie Gdańskowi prawa do ścigania i karania rozbójników, wysłania posła królewskiego do księcia pomorskiego. Większość spraw jednak król odłożył do czasu swojego przyjazdu do Prus ${ }^{16}$.

3. Koronacja królewska miała miejsce 24 stycznia 1507 r. w Katedrze wawelskiej $^{17}$. Następnego dnia rozpoczęły się obrady sejmowe i trwały do 8 marca $1507 \mathrm{r}^{18}$ Nie dysponujemy niestety żadnymi bezpośrednimi relacjami $\mathrm{z}$ ich przebiegu. Nie zachowały się ani diariusze (o ile je sporządzono) przedstawiające przebieg tego sejmu, ani korespondencja jego uczestników, którą w odniesieniu do innych sejmów przekazały Acta Tomiciana. Niewiele informacji zawierają Kroniki Josta Decjusza, Marcina Bielskiego czy Bernarda Wapowskiego. Uniemoźliwia to odtworzenie przebiegu debat. Można natomiast, na podstawie podjętych przez ten sejm uchwal, ustalić przedmiot obrad ${ }^{19}$.

- Zgodnie z pradawnym zwyczajem, król złożył podczas koronacji uroczystą przysięgę konfirmującą wszystkie prawa, wszystkie wolności $i$ swobody królestwa, badź wszystkim wspólnie, badź każdemu $z$ osobna [...] dane $i$ darowane ${ }^{20}$. Tekst tej przysięgi, zgodnej z tradycyjną rotą przysięgi koronacyjnej królów polskich, został włączony do konstytucji wieczystych tego sejmu ${ }^{21}$, zaś $w$ półtora miesiąca po zamknięciu sejmu kancelaria królewska wystawiła przywilej potwierdzający prawa pospolite oraz prawa ziem, który w jednobrzmiącej wersji rozesłano do poszczególnych ziem Korony, w celu oblatowania go $\mathrm{w}$ grodach $^{22}$.

4. Zasadniczym celem sejmu bylo zaspokojenie potrzeb obrony państwa, co w praktyce oznaczało uchwały podatkowe. Król potrzebowal pieniędzy na wojnę $z$ Moskwą. Ostateczny wynik obrad $w$ tym zakresie był zgodny $\mathrm{z}$ życzeniami dworu.

${ }^{16}$ ASPK V, cz. l, nr 18, 19, 21, $23 \mathrm{i}$ in

${ }^{17}$ Opis koronacji Zygmunta I w kronikach: B. W a powskiego, Scriptores Rerum Polonicarum [dalej: SRP] II, Kraków 1874, s. 72-73, oraz J. Decjusza, Ksiega o czasach króla Zygmunta I, Warszawa 1960 , s. 26-27.

${ }^{1 *}$ Chronologia sejmów, nr 15, s. 133. W księgach podkanclerskich Metryki Koronnej ostatni wpis ze wzmianka in conventione Cracoviensi nosi datę 18 marca. Zob. Matricularum Regni Poloniae Summaria [dalej: MS] IV, 2, 8379.

${ }^{19}$ Dorobek ustawodawczy sejmu z 1507 r. zostal zestawiony i opublikowany ostatnio $w$ VC, t. I, vol. 1, s. $185-210$.

26 Corpus luris Polonici [dalej; CIP] III, s. 30-31.

21 VC, s. 187.

${ }^{22}$ CIP III, nr 17, s. 55. 
4.1. Uchwalono unanimi omnium voto pobór wiardunkowy (contributio fertonum) w kwocie 12 groszy $\mathrm{z}$ gospodarstwa o powierzchni 1 lana lub 6 groszy od gospodarstwa póllanowego. Obowiązkowi podatkowemu podlegali chłopi oraz szlachta zagrodowa zwolniona od pospolitego ruszenia, a także wójtowie i soltysi nie posiadający poddanych chłopów. Ten sam podatek placili karczmarze zwolnieni od czopowego, młynarze dziedziczni we wsiach oraz Wołosi od każdej setki owiec. Podatek uchwalono tylko na jeden rok. Szlachtę i duchowieństwo pobierających dochody czynszowe obciążono podatkiem w wysokości czwartej części rocznego czynszu. Opodatkowaniu podlegały także wyderkafy, a więc czynsze pobierane $z$ tytułu renty wieczystej $j^{23}$. Na miasta nałożono na najbliższy rok podatek zwany szosem, płacony od nieruchomości miejskich w wymiarze 2 groszy od 1 grzywny majątku oraz 4 groszy od dochodu wynajmujących się tygodniowo lub kwartalnie na shużbę w miastach ${ }^{24}$. Natomiast na przeciąg najbliższych czterech lat uchwalono podatek od wyszynku piwa, miodu, wina $i$ innych trunków, zwany „czopowem"25. Nałożenie podatków, a zwłaszcza „czwarcizny” od czynszów rodziło u szlachty obawy, aby w przyszłości nie stanowiły one precedensu godzącego $w$ wolności podatkowe. Wymogła ona na królu pisemne zapewnienie $w$ formie osobnego przywileju z 8 marca 1507 r., że uchwalone na sejmie podatki zostały ustanowione nie $\mathrm{z}$ przymusu, lecz całkowicie dobrowolnie pro conservatione tuitioneque reipublicae $\mathrm{i} \mathrm{z}$ tego powodu nie deroguja one konstytucji pospolitych królestwa ${ }^{26}$. Mimo tego formalnego królewskiego zapewnienia „czwarcizna od czynszów” wywołala wśród szlachty liczne protesty. Wezwana na pospolite ruszenie $w$ lecie $1507 \mathrm{r}$. szlachta małopolska odmówiła jej zapłaty ${ }^{27}$.

Na sejmie debatowano również nad świadczeniami podatkowymi duchowieństwa. Chociaż formalna uchwała nie została podjęta in conventione generali, lecz na synodzie duchowieństwa $w K_{\text {Kole }}^{28}$, to już na sejmie

${ }^{23}$ CIP III, nr 8, s. $40-42$; nr 9, s. $42-43$.

${ }^{24}$ CIP III, nr 10, s. 44-45. Całkowicie wolna od podatku została czeladż annuatim serviens.

${ }^{25}$ CIP III, nr 11 , s. $46-48$.

${ }^{26}$ Exactiones et contributiones fertonum, civiles, ducillorum, quarta pars censum et octava pars decimarum per universos principes consiliariosque spirituales et saeculares ac nunctios terrarum regni nostri pro conservatione tuitioneque reipublicae ac sublevando statu regio nostro institutae et laudatae fuerint, tamen quia eiusmodi exactiones non ex debito seu obligatione, sed de eorum libera spontaneaque voluntate ac mero arbitrio laudarunt et instituerunt, ideo ne in futurum lauda presentia constitutionibus regni communibus praeiudicarent, CIP III, s. 50.

${ }^{27}$ O. B a lzer, [w:] CIP III, s. 39-40. Zob. też: A. W y c zańs ki, Z dziejów reform skarbowo-wojskowych za Zygmunta I. Próby reluicji pospolitego ruszenia, PH, 1952, t. XLIII, s. 287-304; A. Sucheni-Grabowska, Monarchia dwu ostatnich Jagiellonow a ruch egzekucyjny, cz. 1: Geneza egzekucji dóbr, Wrocław-Warszawa-Kraków-Gdańsk 1974, s. 23-25.

${ }^{28}$ Synod ten został zwołany przez arcybiskupa Andrzeja Różę Borzyszewskiego pro Ascensionis Domini (13 V) 1507 r. Por. Acta capitulorum nec non iudiciorum ecclesiasticorum selecta, ed. B. Ulanowski, t. I: Acta capitulorum Gnesnensis, Posnaniensis et Vladislaviensi, Monumenta Medii Aevi Historica [MMAeH], t. III, Kraków 1894, nr 1013, 1379, 1381. 
określono wysokość podatku od kleru. Jak wskazuje na to uchwała synodu, poza wiardunkiem od kmieci ze wsi kościelnych oraz czwartą częścią czynszu, obciążenia duchowieństwa na potrzeby obrony miały objąć ponadto: podwójną kontrybucję (contributio dupla) oraz ósmą część wszystkich dziesięcin. Podobnie jak wcześniej szlachta, także duchowieństwo wymogło na królu wydanie specjalnego pisemnego zaręczenia, stwierdzającego, że uchwalenie tych podatków nie może być $w$ przyszlości traktowane jako precedens i nie uszczupli wolności podatkowych duchowieństwa. Dokument ten został wydany $w$ Sandomierzu 24 maja $1507 \mathrm{r}^{29}$

Przeznaczeniem uchwalonych na sejmie podatków był zaciąg wojska na obronę granic oraz pomoc dla Wielkiego Księstwa Litewskiego zagrożonego agresją moskiewską. Dodatkowym zabezpieczeniem obrony była konstytucja wojenna, udzielająca królowi zezwolenia na ogłoszenie pospolitego ruszenia szlachty ${ }^{30}$. Uzupełniono ją zarządzeniem popisu wojennego w poszczególnych województwach. Na oznaczone przez króla miejsca rycerstwo miało się stawić $w$ pełnym rynsztunku bojowym ${ }^{31}$. Od udziału $w$ pospolitym ruszeniu została zwolniona szlachta wielkopolska. W zamian za to jej posłowie zgodzili się, aby przekazać do skarbu królewskiego pobieraną od poddanych każdorazowo w razie wyprawy opłate zwaną "wojenne" (solutio bellica) oraz dodatkowy podatek $\mathrm{w}$ wysokości sześciu groszy $\mathrm{z}$ lana chłopskiego albo połowy szosu, czyli podatku miejskiego ${ }^{32}$.

Poza uchwałami podatkowymi, sejm koronacyjny powziął także inne ważne postanowienia $w$ dziedzinie finansów państwowych. Król z senatem, bez udziału posłów ziemskich, uchwalili wprowadzenie tak zwanego ,nowego cla" na woły i skóry wolowe wywożone na sprzedaż $z$ kraju ${ }^{33}$. Uchwalono także ordynację o biciu nowej monety półgroszowej przez najbliższe cztery lata $^{34}$. Tego rodzaju akt mial na celu sanację obiegu pieniężnego w Polsce. Od pewnego czasu gospodarka kraju cierpiała wskutek zalewu gorszej monety - pólgroszków wybijanych głównie na Śląsku.

4.2. Plon ustawodawczy sejmu koronacyjnego Zygmunta I stanowiły jeszcze inne ważne konstytucje wieczyste, liczące $w$ swej pełnej wersji $w$ druku urzędowym z 1507 r. lącznie 27 artykułów ${ }^{35}$. Ich treść dowodzi, że w znacznej części inicjatywa prawodawcza pochodzila od szlachty, choć nie można

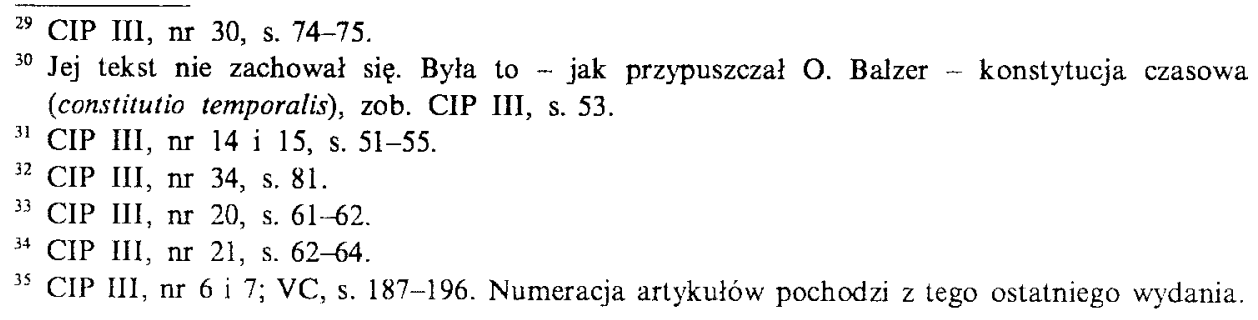


wykluczyć aktywnej roli senatu na tym polu. Dowodzi tego wzmianka $\mathrm{w}$ jednym $\mathrm{z}$ artykułów w brzmieniu: ...petitionibus baronum et nobilium regni nostri annuentes ${ }^{36}$.

$\mathrm{Na}$ wstępie konstytucji zamieszczono artykuły zawierające potwierdzenie i uzupełnienie ustaw Jana Olbrachta i Aleksandra $z$ lat 1496, 1504 i 1505. Chodziło tutaj między innymi o potwierdzenie „wieczności” wpisów w księgach sądowych (art. 3); opatrzenia kanclerzy i sekretarza wielkiego (art. 4); wolności celnych dla szlachty (art. 5); czasu wypowiedzenia służby (art. 7); objęcia trybem nadzwyczajnego pozywania przez starostów ,na skargę" (ad quaerelam), stosowanego $\mathrm{w}$ procesach o wybicie $\mathrm{z}$ posiadania, także $\mathrm{w}$ sprawach o pozbawienie posagu (art. 8). Pozostałe artykuły zawierały przepisy nowe, jakkolwiek tylko nieliczne miały charakter reformatorski i odzwierciedlały szerszą myśl polityczną czy prawną ich inicjatorów, a w szczególności najwybitniejszej postaci na ówczesnej scenie politycznej - kanclerza Jana Laskiego.

Odbiciem, ujawnionych już na sejmie elekcyjnym w 1506 r., projektów Łaskiego zreformowania sądownictwa królewskiego, był artykuł 19 o ustanowieniu przy królu dwóch audytorów sądowych, ,znawców prawa” (iurisperiti auditores), jednego świeckiego i drugiego duchownego. Mieli oni sluchać skarg $i$ te urzédnikom kancelaryjej Królestwa naszego wiernie winni odnosic $c^{37}$. To ta konstytucja dała asumpt do powstania specjalnego sądu królewskiego, zwanego w przyszłości sądem referendarskim ${ }^{38}$.

Nowatorski charakter miał także art. 13, określony jako ,ustawa wieczysta" (statutum perpetuum), ustanawiający zasadę, że jeden z kanclerzy musi być osobą świecką. Ze względu na rolę kanclerzy w rządach państwem, przepis ten miał duże znaczenie. Powoływanie osób duchownych na stanowisko kanclerzy było w Polsce zadawnioną praktyką. Często radzilem - pisał w $1454 \mathrm{r}$. w liście do Kazimierza Jagiellończyka, kardynał Zbigniew Oleśnicki - aby na urzędy dworu twego, a mianowicie do kancelarii, mężów madrych, dojrzalych $i$ czynnych wybieral [...]. Racz WKM przy wyborze na taki urzqd dobrze sie zastanowić $i$ wyszukać męża uczonego, dojrzalego i mqadrego, a przede wszystkim duchownego [...], ponieważ, jeżeli prawde mam powiedzieć, urzędu tego nigdy ludzie świeccy z korzyściq dla Waszej Królewskiej Mości i pansstwa wykonywać nie moga, bo zajeci swymi prywatnymi sprawami, nie mogq oddawać sie sprawom publicznym. A $i$ ojciec Wasza Królewska Mość tak samo czynil. Obowiązek nominacji świeckich na godności kanclerskie wiązal się w praktyce $z$ ograniczeniem swobody króla w doborze swoich najbliższych wspólpracowników.

\footnotetext{
36 VC, s. 190 , art. 13.

${ }^{37} \mathrm{CIP}, \mathrm{nr} 6$, s. 34 , art. 19 ; VC, s. 192, art. 19

${ }^{38}$ Zob. J. R a f a c z, Sad referendarski koronny. Z dziejów obrony prawnej chlopów $w$ dawnej Polsce, Poznań 1948, s. 2-11; J. M atuszewsk i, W sprawie genezy sqdu referendarskiego, CPH 1954 , t. VI, s. 353-357.
} 
Poważne konsekwencje mógł mieć także artykuł 10: De publicis pecuniis dispensandis et conservandis, ograniczający swobodę króla w szafowaniu dochodami publicznymi. Decyzje w tym zakresie miały zapadać przy współudziale senatorów, a to panów radnych, którzy natenczas z nami albo z potomki naszymi będq oraz panów onej ziemie, w której siuszny przyda się czas opatrzenia pożytku pospolitego ${ }^{39}$. Jednocześnie konstytucja zagroziła surowym karaniem za zbrodnię kradzieży mienia publicznego (fraus et peculatus) tym, którzy dopuściliby się jakiegokolwiek bądź zagarnięcia dochodów skarbowych (wzial, uchwycil albo którymkolwiek sposobem na potrzeby wlasne obrócil ${ }^{40}$. Wypada w tym miejscu wyjaśnić, że peculatus było jednym $\mathrm{z}$ najcięższych znanych prawu rzymskiemu przestępstw kryminalnych $^{41}$. Konstytucja sejmowa z 1507 r. $O$ chowaniu skarbu publicznego stanowiła więc przejaw recepcji rzymskiej konstrukcji prawnej peculatus do prawa polskiego ${ }^{42}$.

Pozostałe artykuły zawarte $w$ uchwalonych przez sejm koronacyjny z $1507 \mathrm{r}$. konstytucjach wieczystych stanowiły już to przypomnienie dawnicjszych norm, których skuteczna egzekucja najprawdopodobniej szwankowala, już to były doraźną i z reguly wycinkową regulacją określonych stosunków społecznych czy gospodarczych.

Liczną grupe stanowily przepisy dotyczące handlu, wydane $z$ pewnością na żądanie posłów ziemskich. Należały do nich: nakaz przestrzegania tzw. taks wojewodzińskich, czyli rozporządzeń ustalających ceny maksymalne oraz obowiązujące miary towarów sprzedawanych $w$ miastach (art. 14); polecenie zachowywania zwyczajowych miar sukna (art. 15); potwierdzenie swobody handlu na jarmarkach (art. 20). Ten ostatni artykuł zakazywał ponadto mieszczanom poznańskim korzystania z przywileju wyłączności prowadzenia handlu na terenie ich rodzimego miasta. Zakazano także odbywania targów we wsiach (art. 23). Ustalono równość wag i miar (art. 24).

Wynikiem skarg szlachty na dzierżawców dóbr królewskich był przepis dopuszczający do równego korzystania $\mathrm{z}$ rzeki rozgraniczającej dobra królewskie i szlacheckie wszystkich mieszkających po jej obu brzegach (art. 16). Troskę o bezpieczeństwo i porządek publiczny ujawniały konstytucje nakazujące starostom należytą dbałość o sprawowanie urzędu (art. 12) - analogicznie jak sędziom grodzkim i burgrabiom. W odniesieniu do tych ostatnich ustanowiono zasadę osiadłości w ziemiach, w których pełnili swoje urzędy (art. 22). Zaostrzono też bardzo znacznie kary za pogwałcenie miru

39 CIP III, nr 6, s. 32.

${ }^{40}$ VC, s. 190, art. 10 (9).

${ }^{11}$ Por. Digesta 48, 13, 1-3. Zob.: Prawo rzymskie. Slownik encyklopedyczny, red. W. Wołodkiewicz, Warszawa 1986, s. 115; W. Lit e w sk i, Slownik encyklopedyczny prawa rzymskiego, Kraków 1998, s. 194.

${ }^{12}$ Zob. W. Uruszczak, Korektura praw.., t. II, s. 70. 
zgromadzeń publicznych przez wtargnięcie zbrojno na sejmy, sejmiki czy sądy. Sprawcy mieli podlegać karze gardła i konfiskaty majątku (art. 18) ${ }^{43}$. Powyższe przepisy służyły umocnieniu państwa i zapewnieniu większej skuteczności jego aparatu władzy. W następnych miesiącach były one wprowadzane $w$ życie na drodze królewskich mandatów kierowanych do starostów i wojewodów.

5. Niewiele wiadomo na temat odbywanych na sejmie w $1507 \mathrm{r}$. narad króla i senatu w przedmiocie spraw zagranicznych. Ponieważ trwała wojna z Moldawią, wywołana w 1506 r. najazdem hospodara Bohdana, zdecydowano się na wysłanie do niego poselstwa. Wspólnym posłem Polski, Czech i Węgier miał zostać Stefan Teleky - posel króla Wladyslawa Węgierskiego ${ }^{44}$. Podjęto też decyzję o poselstwie do króla Węgier. Na jego czele stanęli biskup poznański Jan Lubrański oraz marszałek koronny Stanisław Chodecki. W skład poselstwa weszli nadto: kanclerz Jan Laski oraz Krzysztof Szydłowiecki ${ }^{45}$. Posłowie polscy mieli miedzy innymi odbyć rozmowy $w$ sprawie banicji miast pruskich Gdańska i Torunia, ogloszonej przez króla niemieckiego Maksymiliana $\mathrm{I}^{46}$.

$\mathrm{Na}$ sejmie w senacie debatowano także nad możliwością zakończenia sporu z Krzyżakami. Wielki Mistrz Zakonu wystosowal do Zygmunta I list $\mathrm{z}$ gratulacjami objecia tronu w Polsce. Prosił w nim o spotkanie pełnomocników obu stron albo o zgodę na rozjemstwo księcia saskiego Jerzego ${ }^{47}$. Sejm krakowski nie wyraził na to zgody i zdecydował wezwać Wielkiego Mistrza do złożenia w Poznaniu 6 grudnia 1507 r. hołdu lennego. Do jego przyjęcia $w$ imieniu polskiego króla wyznaczono Łukasza Watzenrodego i Ambrożego Pampowskiego ${ }^{48}$.

W czasie sejmu, równolegle $z$ obradami senatu i posłów, król odbywał w asyście senatorów sądy sejmowe. Ferowane przez niego wyroki zostały uwiecznione $w$ Metryce Koronnej pod datami 7, 9, 14, 23, 27 lutego oraz 6 marca 1507 r. ${ }^{49}$

${ }^{43}$ Zob. A. L i 1 y ński, Ochrona sejmików w polskim ustawodawstwie karnym XVI-XVIII w., Przegląd Prawa i Administracji [Wrocław] 1976, (=Acta Universitatis Wratislaviensis $\mathrm{nr}$ 307), 1. VII, s. 229 i n.; tenże, Przestepstwa polityczne $w$ polskim prawie karnym XVI-XVIII wieku, Katowice 1976, s. 97; W. U ruszczak, Korektura praw..., t. II, s. 76.

${ }^{44}$ Kroniki Bernarda Wapowskiego z Radochoniec. Czessć ostatnia czasy podlugoszowe obejmujące (1480-153.5), wyd. J. Szujski, SRP II, Kraków 1874 [dalej: Wapowski], s. 73; Acta Tomiciana. Epistolae. legationes, responsa, actiones, res gestae Serenissimi principis Sigismundi eius nominis primi, regnis Poloniae [...] per Stanislaum Górski [...] collectae, 1. I, Poznań 1852, s. 15.

${ }^{45}$ Wapowski, s. 74.

${ }^{40}$ ASPK V, cz. 1, nr 35, s. 79-80.

${ }^{47}$ W. Pociecha, Geneza holdu pruskiego (1466-1525), Gdynia 1937, s. 32

+* Ibidem. Tekst instrukcji w rękopisie Biblioteki Czartoryskich w Krakowie, nr 1594.

${ }^{49}$ MS IV, 1, nr 9, 13, 14, 33, 39, 77, 78, 79. 
6. Oceniając dorobek Sejmu koronacyjnego z 1507 r., wypada stwierdzić, że byl on sejmem bardzo udanym. Świadczyl o kredycie zaufania, jaki u progu panowania nowo wybrany monarcha uzyskał od poddanych, gotowych do znacznych finansowych ofiar na potrzeby wspólnej obrony. Konstytucje wieczyste były zapowiedzią ważnych reform w dziedzinie sądownictwa, finansów publicznych, bezpieczeństwa. Odzwierciedlały zarazem niedwuznacznie trendy przemian ustrojowych ku wzmocnieniu pozycji prawnej szlachty kosztem innych stanów.

7. $[\mathrm{A} \mathrm{n} \mathrm{e} \mathrm{k} \mathrm{s]}$

Senatorowie obecni na sejmie koronacyjnym w $1507 \mathrm{r}^{50}$

Arcybiskupi:

1. arcybiskup gnieźnieński Andrzej Borzyszewski,

2. arcybiskup lwowski Bernard Wilczek.

Biskupi:

1. krakowski Jan Konarski,

2. włocławski Wincenty Przerembski,

3. poznański Jan Lubrański,

4. plocki Erazm Ciołek,

5. przemyski Maciej Drzewicki, podkanclerzy koronny,

6. chełmski Mikolaj Kościelecki;

Nieobecny: biskup kamieniecki Jakub Buczacki.

Wojewodowie:

1. kasztelan krakowski Spytek Jarosławski z Jarosławia,

2. poznański Jan z Szamotul,

3. krakowski Jan Feliks Szram Tarnowski,

4. sandomierski Mikołaj Kamieniecki, starosta sandomierski i krakowski, hetman wielki,

5. kaliski Mikołaj Gardzina z Lubrańca, starosta łęczycki,

6. sieradzki Ambrozy Pampowski, starosta Malborski,

7. łęczycki Jarosław Laski,

8. brzeski Mikołaj Kościelecki,

9. inowroclawski Mikołaj Kretkowski,

10. ruski Jan Amor Tarnowski,

so Obecność senatorów na sejmie na podstawie wykazów świadków w dokumentach królewskich wystawionych w czasie sejmu 1507 r., opublikowanych w CIP III, nr 6, s. 29, 35-36, oraz w VC, s. 195-196. Do identyfikacji nazwisk posłużła publikacja: Urzędnicy dawnej Rzeczypospolitej XII-XVIII wieku. Spisy. red. A. Gąsiorowski, t. I-X, Kórnik 1990-1992; Urzędnicy województwa podolskiego $X V$-XVIII wieku (powiaty czerwonogrodzki, kamieniecki, latyczowski. Spisy), oprac. K. Przyboś, Kraków 1994. 
11. rawski Prandota z Trzciany,

12. belzki Stanisław Kmita z Wiśnicza;

Nieobecni wojewodowie: podolski, lubelski, plocki.

Kasztelanowie:

1. sandomierski Jakub Szydłowiecki, podskarbi koronny,

2. kaliski Jan Jarand $\mathrm{z}$ Brudzowa,

3. wojnicki Jakub Sieklucki,

4. wiślicki Piotr Szafraniec z Pieskowej Skały, starosta radomski i sochaczewski,

5. lwowski Otto Chodecki z Chodcza,

6. sądecki Jan Lukasz Słupecki,

7. biecki Jan Jordan z Zakliczyna, starosta oświęcimski,

8. radomski Stanisław Szafraniec Młodziejowski,

9. zawichojski Marcin Skotnicki z Bogorii,

10. małogojski Jan Bohotnicki z Oleśnicy,

11. rawski Piotr Niemiglowski;

Kasztelanowie nieobecni: poznański, gnieźnieński, sieradzki, łęczycki, brzeski, inowrocławski, kamieniecki, lubelski, bełski, płocki, międzyrzecki, rogoziński, lądzki, śremski, żarnowski, wieluński, przemyski, halicki, sanocki, chetmski, dobrzyński, połaniecki, przemęcki ${ }^{51}$, krzywieński, czchowski, nakielski, rozpierski, biechowski, bydgoski, brzeziński, kruszwicki $^{\text {52 }}$, oświęcimski, kamieński, spycimierski, inowłocki, kowalski, santocki, sochaczewski, gostyński, raciąski, lubaczowski, konarski sieradzki, konarski łęczycki, konarski kujawski.

Ministrowie nie sprawujący innych godności senatorskich:

1. marszałek wielki Stanisław Chodecki, starosta lwowski i kamieniecki,

2. kanclerz wielki Jan Laski,

3. marszałek nadworny Stanisław Jarocki ${ }^{53}$.

s1 W czasie sejmu, 14 II 1507 r. król nominował kasztelanem przemęckim Hieronima Rozrazowskiego, MS IV, 2, 8319.

${ }_{52}$ Wakująca po przejściu Andrzeja Oporowskiego na kasztelanię brzeską, kasztelania kruszwicka została 19 II 1507 r. oddana Jakubowi Oporowskiemu. Zob. MS IV, 2, 8326.

${ }^{53} \mathrm{Na}$ liście świadków w konstytucjach sejmu z 1507 r. figurują ponadto: starosta generalny wielkopolski Jan Zaremba Kalinowski oraz sekretarz wielki Wojciech Górski (VC, s. 196). 